\title{
State Ethics as the Basicof Legal Policy for Handling of Covid-19 in Indonesia
}

\author{
Zainal Arifin Hoesein ${ }^{1,}$, Pathorang Halim ${ }^{1}$ and Arifuddin Arifuddin ${ }^{2}$ \\ ${ }^{1}$ Faculty of Law Universitas Muhammadiyah, Jakarta 15419, Indonesia \\ ${ }^{2}$ Universitas Islam As-Syafi'iyah, Bekasi 17411, Indonesia
}

\begin{abstract}
The Covid-19 pandemic has created emergencies in all sectors of life around the world. In this context, this study seeks to evaluate the important role of state officials and administrators' ethics as the basis for legal policy in handling Covid-19 in Indonesia. By using a descriptive method with a conceptual approach based on normative-juridical analysis, the results of the study show that law-making and policy implementation in handling Covid-19 should be based on an agreement of ethical, moral, and basic norms as basic legal values. In this context, the constitution must be used as the basis for ethics and moral values in which all State policies as outlined in the form of laws are guided by and by the 1945 Constitution. The conclusions of this study underline the implementation of ethics following the state constitution and theoretically contribute to the constitutional aspect in public policy where policy decisions on handling Covid-19 must remain following the constitution.
\end{abstract}

Keywords: State Ethics, Legal Policy, Handling Covid-19, Constitutions.

\section{INTRODUCTION}

There are at least 3 (three) things that need serious attention in a state, firstly, consensus on shared goals and objectives in the state, secondly consensus based on named good ethical and moral foundation and basic law; and thirdly state mechanisms and procedures (Andrews, 1968). The three substances that consensus becomes very important because three is a base value that standardizes philosophy and theology values, political, and sociological values and also juridical value. Therefore, having a state is a human right of every person and group that is part of political rights and has been recognized and protected by law (Hoesein, 2014). There are at least four (4) instruments is the International law protected political right: first, the declaration of the Universal Human Rights; second, the International Convention on Civil and Political Rights; third, international conventions on the elimination of all forms of racial discrimination; and fourth, Convenience International on the political rights of women (Hoesein, 2009).In the state, all the rights are inherent in every person and citizen of the state because of compulsive attendance in the sense of giving attention (to respect), protection (to protect), and fulfillment (to fulfill) on rights, citizens, constitutional rights and human rights.

The practice and dynamics of the Indonesian state administration are the logical consequences of the dynamics of social, cultural, political, economic, and religious life as well as the effects of globalization that

*Address correspondence to this author at the Jl. KH Ahmad Dahlan, Cirendeu, Ciputat Timur, Jakarta 15419, Indonesia; Tel: (021) 7490385; Fax: (021) 7432590; E-mail: zainalhoesein.umj@gmail.com cannot be limited and contained, especially related to the progress and application of information technology. These things must be interpreted as a part of the process and application of instincts of procreation, the instinct of survival, and the instinct of worship of every human being that develops into parts of the institutions of society and the state (Lallement, 2014). In this perspective, the Indonesian constitution namely the 1945 Constitution (UUD 1945) was formed and built by national leaders, both during the formulation of 1945 and during the amendments of 1999-2002 (Yamin, 1945). Therefore, at the philosophical level, the constitution is an accumulation of ethical and moral values (pholosophischegrondslag) as well as a basic norm (grundnorm) which was born as a political agreement and legal decision which is placed as the basic law of state administration (Kelsen, 1999).

Principally, the 1945 Constitution contains moral values and ethics of the nation in the state, becoming the basic law in the administration of community, nation, and state life, so its position as the highest of constitutions law (Asshiddiqie, 2006). The existence of the Constitution in a country is meant as, first, a national document; second, a political-legal document; and third, a birth certificate (van Maarseveen\& van der Tang, 1978).

This position gives the consequence that the constitution has an important and high position in the state because the constitution is essentially that will divide and limit power within the state (Martosoewignjo, 2002; Soemantri, 2006; Asshiddiqie, 2006).To maintain the position of the constitution as the ethical and moral basis of the nation, and at the same time as a basic 
law, a legal instrument is needed which gives certain powers to assess and determine the constitutionality of a legal product in the form of a law. The contradictory nature of the lower law results in the cancellation of the law's validity. Conversely higher law is the basis and source of a lower law. The higher the legal position in its rank, the more abstract and general the nature of the norm it contains. Conversely the lower the rank, the more real or concrete the nature of the norm they contain.

At the theoretical level, various scholars agree that the state is an organization of power. In the doctrine of power, there is an adage that "power tends to corrupt". This condition will not occur if power is managed in a just and democratic manner, transparent and accountable, and participatory. Matters related to signs and limitation of power settings have been stated in the constitution in this respect the 1945 Constitution. Therefore, the constitution is the source of ethical, moral, and legal, that state as or know power and officials state as enforcers (amdrager) is bound by the ethical, moral, and legal values that form the spirit of a national constitution.

\section{COVID-19 AS PUBLIC HEALTH EMERGENCY}

The famous statement and position of Marcus Tullius Cicero (106-43 BC) is, salus populi suprema lex esto (people's salvation is the highest law) is teaching in legal philosophy. The statement shows that law should lead to the human or law for the person and not merely amplify the power. The covid-19 pandemic has had a devastating effect on several sectors such as the economic sector especially industry, social, education, healthy lifestyle, and other socio-cultural. The level of spread of this virus is so fast and massive so that it has a considerable impact on the structure of the economy, social culture, and lifestyle of the people in Indonesia. Therefore, the state that must protect the citizens of the nation as stated in the fourth paragraph of the Preamble of the 1945 Constitution, through the government has been issued Presidential Decree Number 12 of 2020 Regarding Non-Natural Disaster Determination of Corona Virus Disease 2019 (Covid19) as National Disaster. Presidential Decree No. 12 Tahun 2020 concerning the Determination of NonNatural Disasters Spreading Corona Virus Disease 2019 (Covid-19) as a National Disaster was stipulated by the President of Indonesia on April 13, 2020, with consideration, a. that non-natural disasters caused by the spread of Corona Vints Disease 2019 (COVID-19) have increased the number of victims and property losses, the expansion of the area affected by the disaster, as well as having implications for broad socioeconomic aspects in Indonesia; b. that the World Health Organization (WHO) has declared COVID-19 as a Global Pandemic on March 11, 2020. The stipulation policy regarding the spread of Covid-19 as a national disaster, the condition that resulted was to put the country in a state of a health emergency. Because the State is in a state of a health emergency, the State can take extraordinary measures (ordinary policy) to tackle the spread of Covid-19 in the framework of protecting, protecting, and fulfilling the community's right to a healthy environment within the framework of fulfilling the rights and life and livelihoods of the citizens of the Indonesian nation guaranteed by the constitution.

The national policy by establishing Indonesia in a state of national disaster due to the spread of Covid-19 is appropriate in the framework of taking large and strategic actions to save the public from the Covid-19 outbreak by referring to Law Number 6 of 2018 concerning Health Quarantine ratified on 7 August 2018 and promulgated on 8 August 2018. In explanation of Act No. 6 of 2018 On Health Quarantine state that; " Indonesia as a part of the world community, is obliged to prevent a deterrent to the occurrence of a public health emergency that is troubling the world (Public Health Emergency of International Concern) as mandated in international regulations in the field of health (International Health Regulations/IHR200s). In carrying out this mandate, Indonesia must fully respect the dignity, human rights, basics of one's freedom, and universal application"; "International Health Regulations (LHR) in 2005 requires Indonesia to increase its capacity and capability in health surveillance and response, and Health Quantity in the region and at the entrance, both ports, airports, and State Cross-border Posts. For this reason, it is necessary to adjust the set of laws, organizations, and resources related to Health Quarantine and its implementing organizations. This is because the existing legislation related to Health Quarantine, namely Law Number 1 of 1962 concerning Sea Quarantine and Law Number 2 of 1962 concerning Air Quarantine, is no longer relevant to current conditions. At that time the two laws referred to the international health regulation called the International Sanitary Regulations (ISR) in 1953. Then the ISR was replaced with International Health Regulations (LHR) in L969 with an epidemiological approach based on the capabilities of the epidemiological surveillance system. World Health Assembly in 2005 had succeeded in 
revising the IHR in 1969 to become the IHR in 2005 which is in force since June 15, 2007".

Referring to the explanation of Law No. 6 of 2018 concerning Health Quarantine, the national policy on health quarantine is a strategic effort to deal with outbreaks of viruses including Covid-19 by declaring a national disaster and can be categorized as health mice. Covid-19 is designated as a medical emergency as outlined in Presidential Decree No. 12 of 2020 is the right that forms the basis of strategic policymaking and the response of the Covid-19 technical outbreak as a national disaster that is at the core of health emergencies.

\section{THE CONSTITUTION AS A SOURCE OF ETHICAL AND MORAL VALUES}

The constitution is the ethics and moral values of the nation as well as containing the basic rules in the state. As an idea, the constitution is a normative set that reflects the values that develop in a society or nation both in terms of social, economic, cultural, political aspects, and others. Normative ties are accommodated from the undercurrent and political elites of a country which is intended as a limitation of state power so that power is not arbitrary. Therefore, the constitution as a basic law that has the meaning of forming is the process and basis of the formation of the state. Also, the constitution serves as the main foundation for the administration of the state and becomes the highest law in a country. Besides, the constitution functions as a limitation of state power, so that the implementation of state power is not arbitrary. This is with the hope that citizens' rights can be protected and there is a balanced relationship between rights and obligations.

Thompson (1997) formulated that the constitution is a document that counts the rules for the operation of an organization. The constitution is a written document containing moral and legal values as the basis for implementing governance. Therefore, the constitution can be interpreted as a basic norm that describes the entire system of government of a country, sets of rules that define namely, bodies of legislative, executive, and judicial branches; relations between state power agencies, and internal relations of state power agencies (Wheare, 1951; Strong, 1930). In this sense, the state as an organization of power is reflected in its constitutional texts in terms of both regulating nature and limiting state power. In principle, every power will be related to the authority and authority inherent in the national organization as an organization of power (Bagir, 2005).

From a sociological perspective, power is always in tandem with the organs that serve the public good mover of social activities related to the individual as a member of the community as well as motion an organspecific community because of the inherent skills and become the focus of social activity. Habermas (1984) view a social paradigm must be approached from the point of view of social reality and the systems which are both interrelated.

Therefore, the social system in principle is a world of life (real-life system), which draws the social life conditions that occur and are felt and experienced by the community concerned. Social structure and social behavior is a picture of the conditions of social significantly either experienced by individuals or the structures at the organs of society which are crystallized into the views and values of good ethics, morals, and rules or legal norms that are religious and communal. The events and conditions that each have a dependence on each other mainly on the functions of system integration, namely the ideal values that are formulated and believed with the social reality that occurs (Habermas, 1975). Each system social always has value systems that guide the interaction between members of the public. In the real-life system, the value system is manifested in ethics and morals that are universal and affect human behavior related to moral values, justice, truth, and goodness (Suseno, 1991; Fletcher, 1997)

The state ethics is a mirror and behavior of the state administrators and the people concerned in the association between state power organs, between citizens/citizens with state power organs, and between members of the community/citizens. The country is initiated by a consensus between community groups relating to shared ideals and goals, the foundation of the state, and the mechanisms, processes of state management or state governance (Andrews, 1968).

The main foundation for the formulation of constitutional norms refers to universal values that have been accepted and are inherent in society so that norms are inseparable from an understanding of values and morals. In essence, value is the extraction of an event that becomes a reality of an individual and social behavior that gives rise to a certain belief in truth and goodness, truth and certainty. In this paradigm, the 
constitution is loaded with values, ethics, and morals as well as the principles of truth and justice, all of which are aimed at the value of the benefit of living in a country. Thus, the constitution is a source of values, moral ethics, and legal norms in the state in the framework of realizing the objectives of statehood as affirmed in the fourth paragraph of the Preamble of the 1945 Constitution.

\section{ETHICS AND CONSTITUTION AS THE BASIC OF LEGAL POLICIES IN HANDLING COVID-19}

Ethics is a science that addresses the problem of human actions or behavior that can be judged as good and not good. In the view of William (1957), ethics is an assessment of right or wrong behavior, good or bad, or similarly to formulate that ethics is a science that is specific and systematic and exhaustive about a series of events or objects related to certain behaviors (Edwards, 1967; Foot, 1967). Therefore, ethics always explores the parameters of good and bad values that are reflected in human behavior as individuals and social behavior as a mirror of culture. In this perspective, ethics becomes the main parameter and reference in evaluating the consistency of community members, citizens, and state administrators to hold tightly and meet the basic norms contained in the 1945 Constitution.

Ethics are an indigenous character custom decency or late, closely related to the moral significance on measures of the value of good and bad. Although the definition of ethics and morals are more or less the same, there are differences, namely morality is used to assess the actions carried out, while ethics is used to assess the applicable value system. Ethics is a branch of philosophy that talks about moral values and norms that determine human behavior in his life. Ethics and morals are values that are indispensable for every citizen, especially national organizers or public officials. By the provisions of Article 1 number 1 of Law Number 28 of 1999 concerning State Administrators that are Clean and Free of Corruption, Collusion, and Nepotism, the meaning of State administrators is, " State Officials who carry out executive, legislative, or judicial functions, and other officials the main functions and duties relating to the administration of the country by the provisions of the applicable laws and regulations".

The state organizer has a very important role in realizing the goals of the country as stipulated in the fourth paragraph of the Preamble of the 1945
Constitution of the Republic of Indonesia, which is to protect all Indonesians and all of Indonesia's blood and to promote public welfare, develop the life of the nation and participate in carrying out world order based on independence, eternal peace, and social justice. To realize professional state administrators, each state organizer must fulfill the requirements as a state organizer as stipulated in statutory regulations, while to realize ethical state administrators, ethical regulations are required in legislation. The regulation must be general so that it applies to every state organizer. From the perspective of the principles of good governance, every state organizer must obey the principles and submit to the principles of good governance. State administrative law emphasizes that public office organizations and public officials are instruments of state power that are carried out within the framework of the spirit of the country's constitution.

Therefore, exclusive power, and the nature of discretion in decision-makers, as well as a lack of accountability in the administration of power can result in the proliferation of acts of abuse of power, so that any power attached to the institution (the State) is always related to the nature of monopoly, discretion, and accountability. The more centralized the power, the stronger the chance of abuse of power in the center of power. Referring to the power and authority inherent in such a large and strategic representative institution, then the nature of monopoly, discretion, and accountability must be maintained and used appropriately, fairly and bring benefits to the life of the nation and society in the long term and lead to the improvement of shared prosperity. In this perspective, the basic and universal values of honesty, trustworthiness, example, sportsmanship, discipline, work ethic, independence, tolerance, shame, responsibility, safeguarding self-respect, and dignity as citizens of the nation must be developed and formulated in the code of ethic of the State implementing agency.

In the perspective of handling Covid-19, if the state officeholders do not heed the constitution and other laws and regulations, then it is equally disregarding the values and morals in the state as well as changing the ethical and moral values contained in the constitution and other laws and regulations damage the consensus in the state. Therefore, the strengthening of ethics and morals in the state of the state public officials and citizens has a very strong influence on the handling of the Covid-19 outbreak in Indonesia. 


\section{CONCLUSION}

Covid-19 as an epidemic has been able to change the patterns of behavior of the world's people, and social groups, because many countries impose strict social restrictions (lock-down), and have even been able to change patterns of relations between countries. Therefore, policies in the framework of dealing with Covid-19 must still refer to and uphold the constitution as a source of ethical and moral values in the nation and state. Not justified authority attached to the organizers of the State irrespective of ethical and moral values.

All policies issued state in this government if avoid or no heed to ethical and moral values of the constitution, the policy will face public rejection. Therefore, the government is part of the state power organ. Being submissive and obedient and ethical and upholding the moral values contained in the constitution, then the policies taken will be certain of fair and civilized humanity value always call to reason that is reasoned. The truthness that reasoning is a value that becomes a source of formulating moral manifested in mindset, attitude, behavior or patterns of follow-though abstract, and then formulated on a practical level in the form of norms agreed and binding and forcing (dwingen), so that the mindset, attitude patterns and patterns of action and obedience are manifested in the lives of individuals, groups, communities, nations, and countries. Therefore, values, morals, and norms are a sequence that must not be broken in the formulation of public policies, so that these policies always rely on reasoning truth (orthos logos) and justice to realize fair and civilized honor and humanity.

Thus, for each power and authority inherent in every state organizer, the moral and ethical foundation as the basis for the integrity of the state administration reflected in the constitution and legislation must be a major factor in assessing and testing its performance which is realized in the form of valuable policies and respectable in the framework of increasing the dignity and value and fair and civilized humanity values for all Indonesian people. Thus, each state organizer must have a strong ethical and moral foundation so that its policy products do not contend with the mandate of the constitution in the framework of accelerating the handling of the Covid-19 outbreak.

\section{REFERENCES}

Andrews, W. G. (Ed.). (1968). Constitutions and constitutionalism (Vol. 1). van Nostrand.

Asshiddiqie, J. (2006). Constitutions and Constitutionalism Indonesia [Indonesian]. Jakarta: Secretary General and Registrar of the Constitutional Court of the Republic of Indonesia.

Bagir, M. (2005). Welcoming the Dawn of Regional Autonomy [Indonesian]. Yogyakarta: Pusat Studi Hukum UII.

Edwards, P. (Ed.). (1967). Encyclopedia of philosophy. New York: Macmillan.

Fletcher, J. F. (1997). Situation ethics: The new morality. Louisville: Westminster John Knox Press.

Foot, P. (Ed.). (1967). Theories of Ethics. Oxford: Oxford University Press.

Habermas, J. (1975). Legitimation crisis. Boston: Beacon Press. https://doi.org/10.3817/0975025210

Habermas, J. (1984). The theory of communicative action. Boston: Beacon press.

Hoesein, Z. A. (2009). Judicial Review at the Supreme Court of the Republic of Indonesia [Indonesian]. Jakarta: Rajawali Press.

Hoesein, Z. A. (2014). Law and Social Dynamics [Indonesian]. Jakarta: Ramzy Putra Pratama.

Kelsen, H. (1999). General theory of law and state. The Lawbook Exchange, Ltd.

Lallement, M. (2014). Réponse de l'auteur au compte rendu de lecture de Nathalie Heinich sur, Michel Lallement. Tensions majeures. Max Weber, l'économie, l'érotisme. Travail, genre et societes, (1), 222-225. https://doi.org/10.3917/tgs.031.0222

Martosoewignjo, S. S. (2002). UUD 1945: Position and Aspects of Change [Indonesian]. Bandung: Universitas Padjadjaran.

Soemantri, S. (2006). Procedures and systems for constitutional change [Indonesian]. Bandung: Alumni.

Strong, C. F. (1930). Modern political constitutions: an introduction to the comparative study of their history and existing form. London: GP Putnam's sons.

Suseno, F. M. (1991). Basic Ethics: Basic Problems of Moral Philosophy [Indonesian]. Yogyakarta: Kanisius.

Thompson, B. (1997). Textbook on constitutional \& administrative law. Oxford: Blackstone Press.

van Maarseveen, H. T. J., \& van der Tang, G. F. (1978). Written constitutions: a computerized comparative study. Leiden: Brill.

Wheare, K. C. (1951). Modern constitutions. Oxford: Oxford University Press.

William, L. (1957). An Introduction to Ethics. New York: Barnes Noble.

Yamin, M. (1945). The Preparation Manuscript for the 1945 Constitution [Indonesian], (Vol. 1). Jakarta: Yayasan Pranpanca.

(C) 2021 Hoesein et al.; Licensee Lifescience Global.

This is an open access article licensed under the terms of the Creative Commons Attribution Non-Commercial License (http://creativecommons.org/licenses/by-nc/3.0/) which permits unrestricted, non-commercial use, distribution and reproduction in any medium, provided the work is properly cited. 